\title{
Distribution of Corynepteris Baily in Dobrudzha Coalfield, NE Bulgaria
}

\author{
Yanaki G. Tenchov \\ Geological Institute, Bulgarian Academy of Sciences, Sofia 1113, Acad. G. Bonchev St., Block 24; \\ e-mail:ytenchov@abv.bg \\ (Accepted for publication: November 2010)
}

\begin{abstract}
Most of the specimens of Corynepteris collected from the Dobrudzha Coalfield sequence are small parts of pinnae. Two species - C. angustissima and C. coralloides predominate. The habitat of Corynepteris had been studied for a long time. The genus occurs in several units of clastic sediments deposited under fluviatile conditions across the prospected part of the depression, but is absent above the coal seam $\mathrm{m} 9$ (middle Bolsovian). When the swamp conditions were restored briefly (coal seams $\mathrm{n}_{1}-\mathrm{n}_{4}$ ) or for a longer time (Gurkovo Formation) the genus did not resettle in the depression. The nearest basin with the genus Corynepteris presented at that time is in the Czech Republic, more than $800 \mathrm{~km}$ away, which was too far for an effective reintroduction of the genus to the Dobrudzha Coalfield. Spores of the genus range up into the Westphalian D coal seam $\mathrm{n}_{3}$.
\end{abstract}

Tenchov, Y. G. 2010. Distribution of Corynepteris Baily in Dobrudzha Coalfield, NE Bulgaria. Geologica Balcanica, 39(3), 13-20.

Keywords: Carboniferous, Dobrudzha Coalfield, Corynepteris, habitat, palaeoenvironment.

\section{INTRODUCTION}

The stratigraphic subdivision of the Dobrudzha Coalfield used in the present study is that described by Tenchov (1993). About 150 slabs with Corynepteris have been found from the Namurian $\mathrm{C}$ to middle Bolsovian Mogilishte and Makedonka Formations in the Dobrudzha Coalfield. Rarely spores are found even higher - in the Krupen Formation (personal communication by Dr. T. Dimitrova). Figure 1 presents the vertical distribution of Corynepteris species and palynomorphs in the basin. The distribution of the genus in the coalfield is discussed in connection with changes in sedimentation and climatic conditions in the region.

\section{MATERIAL}

The total Dobrudzha Coalfield collection consists of 11400 samples from mainly full core drillings in the coalfield. About 150 of these specimens (1.3\%) belong to three species of Corynepteris, which are thus among the best represented of the 300 megafloral species in the collection. The specimens are mainly fragments of pinnae. They occur when a coal seam roof is of claystones. Analysis of the boreholes in the coalfield where the specimens were collected from shows that nearly all were from the central part, quite rarely from the southern part (R 104 and R110 - C. angustissima only), but in that case from the cover of the first coal seam $-1_{1}$. The distribution indicates a close relation to coal seams, and thus to swamp conditions.

The data on the vertical distribution in the Dobrudzha Coalfield are based on the determination of all collected specimens. The distance indicated as "standard level" (SL) is used for correlation between boreholes. It is measured either from above coal seam $1_{1}$ (accepted as $0 \mathrm{~m}$ ), from below or above coal seam $\mathrm{m} 5$ (accepted as $670 \mathrm{~m}$ ) or from below or above coal seam $\mathrm{n} 1$ (accepted as $920 \mathrm{~m}$ ) for the samples from a drill, depending on which seam is nearest; for the lower part of the Makedonka Formation (Mab) SL values are taken as from 657 to $668 \mathrm{~m}$ (see Fig.1). The recently recommended chronostratigraphic terms Langsettian, Duckmantian and Bolsovian are used by replacement of Westphalian A, $B$ and $C$, respectively.

\section{TAXONOMY}

Brousmische (1983) included in the description and figures of the genus Corynepteris the available information for fertile plants with established connection with sterile parts. For some plants regarded as belonging to 


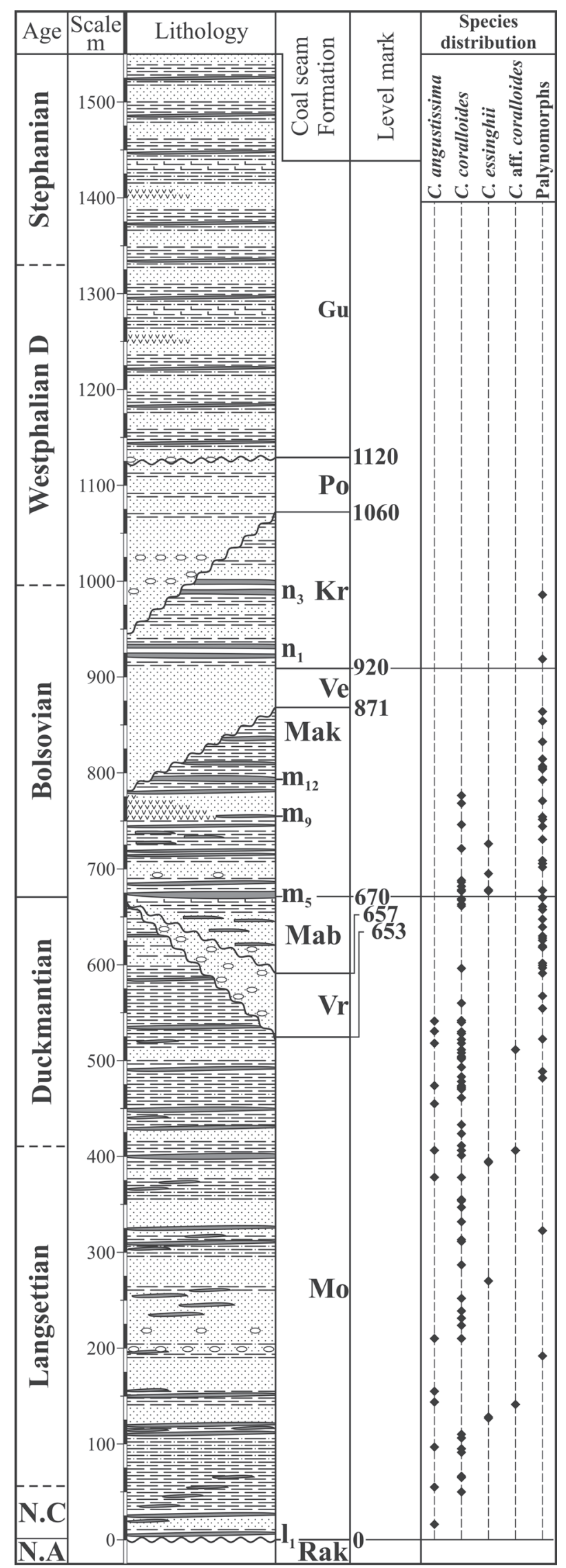

Fig. 1. Corynepteris and palynomorph distribution in Dobrudzha Coalfield sequence: Rak - Rakovski Formation; Mo - Mogilishte Formation; Vr - Vranino Formation; Mab - Makedonka Formation bellow $\mathrm{m}_{5}$ coal seam; Mac - Makedonka Formation above coal seam $\mathrm{m}_{5}$; Ve - Velkovo Formation; $\mathrm{Kr}$ - Krupen Formation; Po - Polyantsi Formation; Gu - Gurkovo Formation; $\mathrm{l}_{1}, \mathrm{~m}_{5}, \mathrm{~m}_{9}, \mathrm{~m}_{12}, \mathrm{n}_{1}, \mathrm{n}_{3}-$ coal seams

the genus, the sporangia are still not known. For them the generic name Alloiopteris Potonie is applied. Such plants are not established in Dobroudzha Coalfield. Except for Corynepteris aff. coralloides, no new taxonomic observations to the determined taxa are made. The main publications consulted are those with the holotypes and several complete publications which concern the genus. For Corynepteris angustissima (Sternberg) Němejc they are: (Sternberg, 1820-1838) - pl. 23, fig. 1; (Němejc, 1938) - pl. 1, figs 3, 4; pl. 3 figs $8-10$; text figs 4, 5, 9b; (Brousmische, 1983) - pl. 1-3, (pl. 3 fig. 8 - part of the type); text fig. 9 , table 8 . For Corynepteris coralloides (Gutbier) Zeiller they are (Gutbier, 1835) - pl. 5, figs 8, 8a; (Zeiller, 1886-88) - pl. 10, figs 1-5; (Němejc, 1938) - pl. 1, fig. 1, 2; pl. 2 figs 1-3, text-fig. 9a.; (Daber, 1955) - pl. 10, fig. 1 (neotype), pl. 25, fig. 3; text fig. 3; (Brousmische, 1983) - pl. 12, text-fig. 17. For Corynepteris essinghii (Andrae) Zeiller they are (Andrae, 1865-1969) - pl. 7, figs 2, 3; (Zeiller, 1886-88) - pl. 9, figs 1, 2; textfig.41; (Němejc, 1938) - pl. 1, figs 5-7, pl. 2, figs 4-6; text-figs 6, 9c; (Brousmische, 1983) - pts. $7-11$, text fig. 14.

\section{Corynepteris angustissima (Sternberg) Němejc}

Fig. 2a-d

Remarks. In compressed specimens the naturally macerated coal substance formed a cover. In such cases details are not well observed. Our well preserved impressions of pinna do not have abnormal pinna at the base, as figured by Brousmische (1983).

Occurrence. C. angustissima is rare in the Mogilishte Formation (at SL 16, 55, 97, 144, 155, 210, 378, 406, $455,474,518,528,541 \mathrm{~m}$ ), that is from Namurian $\mathrm{C}$ to lower Duckmantian.

Stratigraphic and geographic distribution. This species is known from Namurian $\mathrm{C}$ to lower Stephanian of Canadian, West European, Czech, Donets, and Turkish coal basins. In the Bulgarian Svoge Coalfield (Tenchov, 1977) it occurs rarely from Namurian $C$ to Lower Duckmantian.

\section{Corynepteris coralloides (Gutbier) Zeiller}

Fig. 2e-g, Fig. 3f

Occurrence. In the basin it is frequently collected in the Mogilishte Formation: in the Namurian C part at SL 50, 65, $66 \mathrm{~m}$; in Langsettian at SL 91, 95, 106, 110, 210, 224, $231,239,252,261,287,311,313,332,347,354,355$, 378, 401, 406 m.; in Duckmantian at SL 411, 422, 433, $433,461,470,471,472,474,478,483,493,502,503$, 

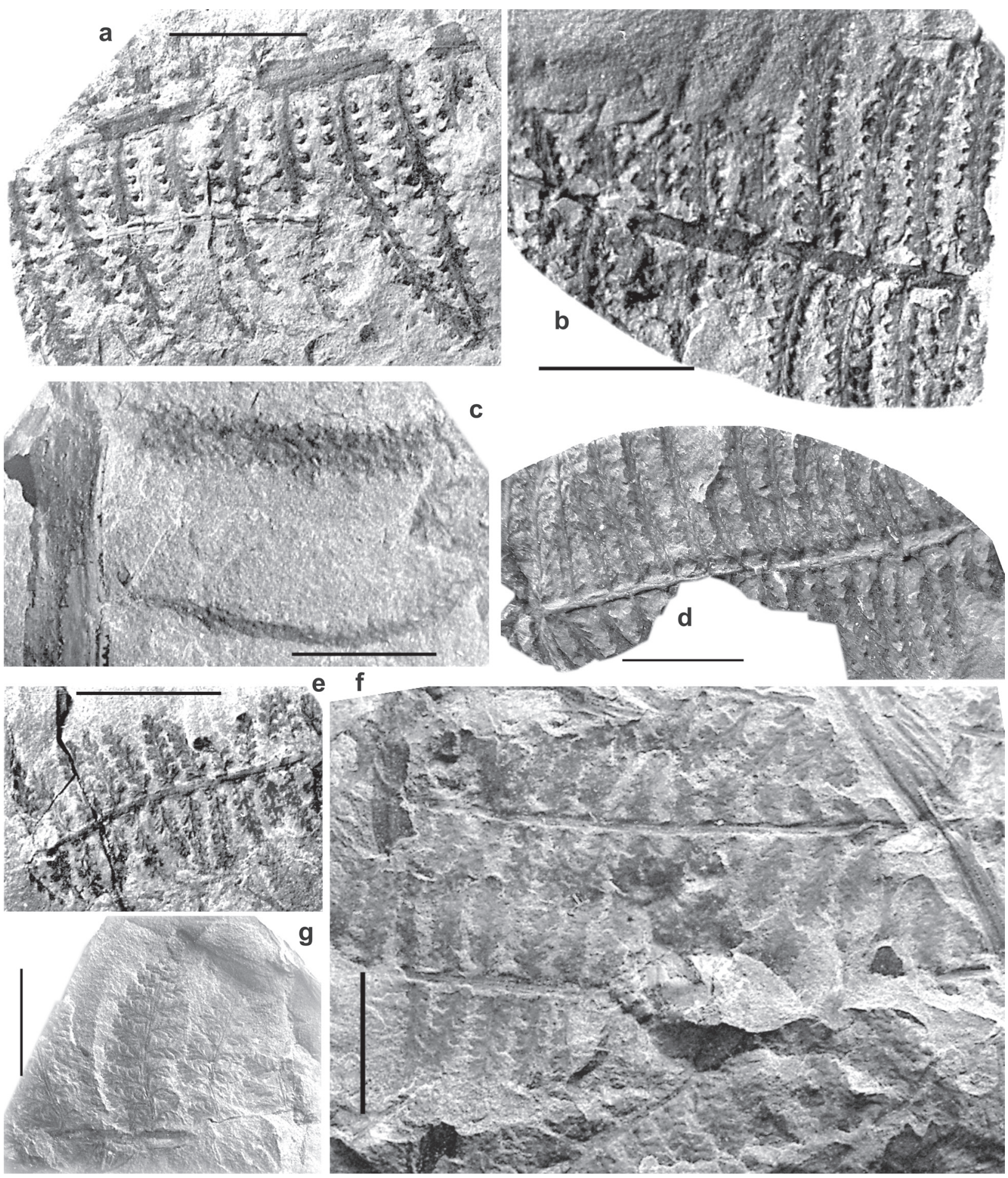

Fig. 2. All Corynepteris species from Dobrudzha Coafield. The bar is $1 \mathrm{~cm}$.

a-d. Corynepteris angustissima (Sternberg) Nemejc

a, specimen 8473, drill 90, depth 1633 m, Mogilishte Fm, SL 455, Duckmantian;

b, specimen 11854, drill 112, depth 1804 m, Mogilishte Fm, SL ?541, Bolsovian;

c, specimen 6045, drill 65, depth 1844 m, Mogilishte Fm, SL 518, Duckmantian;

d, specimen 11127, drill 104, depth 1877 m, Mogilishte Fm, SL 16, Namurian C.

e-g. Corynepteris coralloides (Gutbier) Zeiller

e, specimen 9813, drill 70, depth 1906 m, Mogilishte Fm, SL 522 Duckmantian;

f, specimen 7214, drill 79, depth 1839 m, Mogilishte Fm, SL 411 Duckmantian;

g, specimen 8369, drill 90, depth 1376 m, Makedonka Fm, SL 746 Bolsovian. 

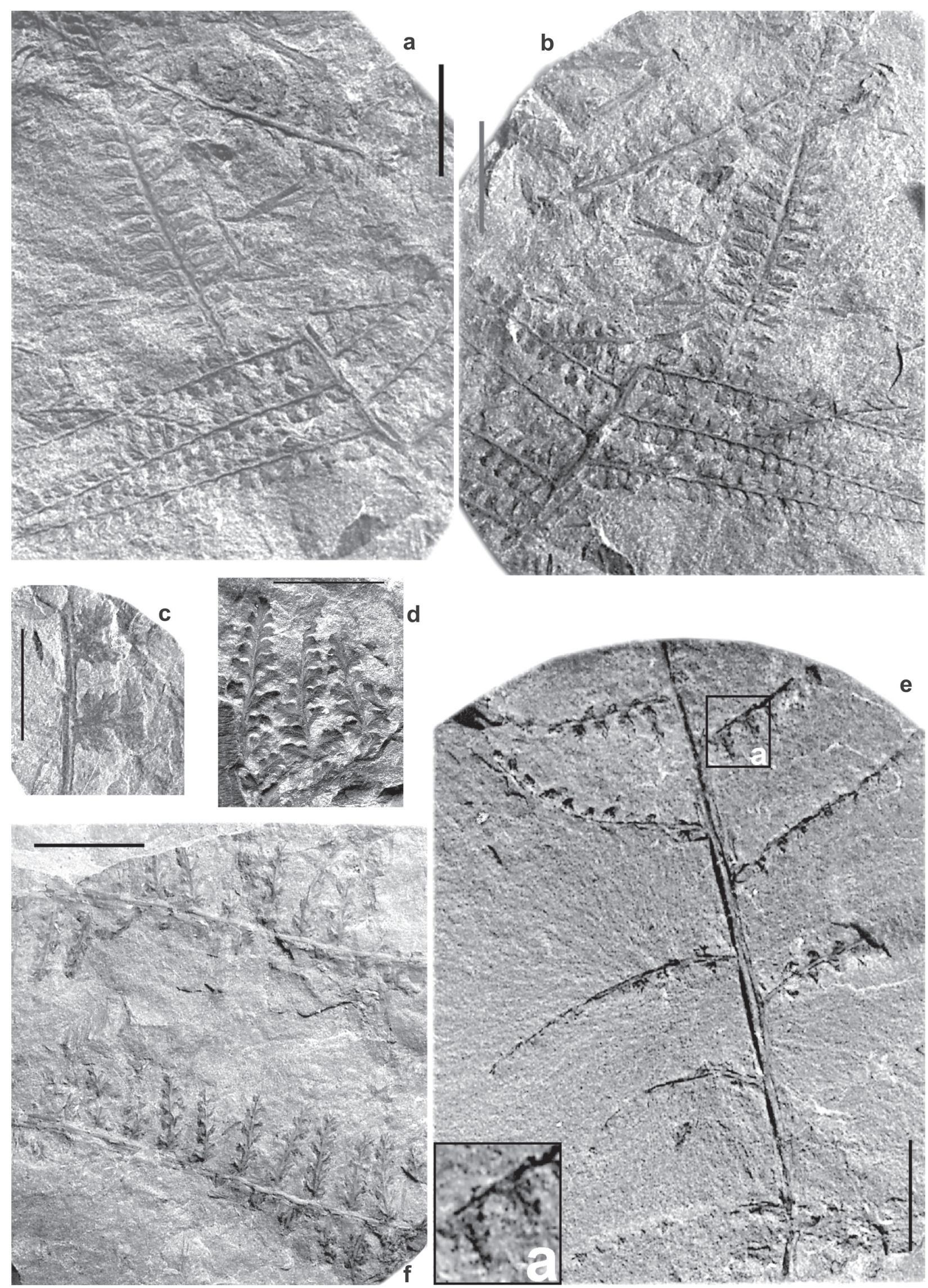
Fig. 3. All Corynepteris species from Dobrudzha Coafield. The bar is $1 \mathrm{~cm}$.

a-d. Corynepteris essinghii (Andrae) Zeiller

a, specimen 11658, drill 100, depth 1627 m, Mogilishte Fm, SL 128 Namurian C;

b, specimen 11664, drill 100, depth 1628 m, Mogilishte Fm, SL 127 Namurian C;

c, specimen 5633, drill 54, depth 1962 m, Makedonka Fm, SL 678 Bolsovian;

d, specimen 13060, drill 144, depth 1409 m, Mogilishte Fm, SL 394 Duckmantian.

e. Corynepteris aff. coralloides (Gutbier) Zeiller

specimen 6044, drill 65, depth 1844 m, Mogilishte Fm, SL 518 Duckmantian.

f. Corynepteris aff. coralloides (Gutbier) Zeiller

specimen 6506, drill 73, depth 1561 m, Mogilishte Fm, SL 231 Langsettian.

$504,508,511,518,522,528,530,540,541,560,596$ $\mathrm{m}$; in the Makedonka Formation (Mab) below coal seam m5 (still in the Duckmantian) at SL 661 663, 667, 668, $668 \mathrm{~m}$; in the Makedonka Formation above coal seam m5 (Mac) at SL 678, 682, 686, 688, 721, 746, 769, $776 \mathrm{~m}$ (in the middle Bolsovian).

Stratigraphic and geographic distribution. The species is known from the Langsettian to lower Westphalian $\mathrm{D}$ in West European coal basins and the Sydney Coal Basin (Canada). In the Svoge Coalfield it is rare in the Bolsovian.

\section{Corynepteris aff. coralloides}

Fig. 3e

Remarks. Three samples show rather widely spaced pinnae with small rounded pinnules that resemble C. coralloides (see the inlet on Fig. 3e). They are not similar to any other figured specimen.

Occurrence. Specimens were collected from SL 141, 406 and $518 \mathrm{~m}$. of the Mogilishte Formation - Langsettian and Duckmantian.

\section{Corynepteris essinghii (Andrae) Zeiller}

Fig. 3a-d

Remarks. One of our samples (11568 with counterpart 11664) demonstrates different shape and size of pinna, as they are shown by Brousmische (1983) on her text fig. $14-\mathrm{A} 1$ to $\mathrm{A} 5$.

Occurrence. In the basin the occurrence of the species is rare - from Mogilishte Formation at SL 127, 128, 270, 394, 395, and from Makedonka Formation at SL 677, $678,695,726$, i.e. from middle Langsettian to lower Bolsovian.

Stratigraphic and geographic distribution. The species is known from the upper Duckmantian and Bolsovian in the Saar Basin and Czech Republic.

\section{LIVING CONDITIONS AND POSSIBLE REASONS OF DISAPPEARANCE}

Figure 4 illustrates the lithological changes through the lower part of the Dobrudzha Coalfield succession and the distribution of the Corynepteris species. The specimens were all collected near coal seams. In the Mogilishte Formation between SL 60 and $200 \mathrm{~m}$ sandstones prevail due to development of braided river plain conditions. Few specimens of the genus were found there. In the next $200 \mathrm{~m}$ (SL 200 to $400 \mathrm{~m}$ ) there are thin coal seams and Corynepteris is more frequent. From SL 400 to $540 \mathrm{~m}$ coal seams are even more frequent and thicker, maybe indicating larger swamps, and Corynepteris is even more frequent.

The higher levels of the Mogilishte Formation are only preserved in restricted parts of the coalfield, where they have escaped the erosion prior to the deposition of the Vranino Formation. Corynepteris occurs rarely only here, although coal seams are frequent.

The Vranino Formation is composed of fluvial sediments, and fossil plants consist mainly of rare but large stems of Calamites and Lycophyta. Corynepteris is missing from this interval, may be due to the destruction of the delicate pinnae of this genus during transportation.

The lower part of the Makedonka Formation (Mab - below coal seam $m_{5}$ ), which again consists mainly of fluvial sediments and several pits of restricted distribution (Tenchov, 1993, Figs 4, 5) has yielded specimens of Corynepteris coralloides, the sporomorphs being frequently found in the coal seams.

In the Makedonka Formation between coal seams $\mathrm{m}_{5}$ and $\mathrm{m}_{9}$ (Mac) laterally extensive coal seams and lake deposits occur across the prospected part of the basin (Tenchov, 2007) and Corynepteris and their spores are well represented. In the upper part of the Makedonka Formation, from coal seam m 9 upwards, Corynepteris specimens are rarer, maybe because the coal seams are preserved at fewer places (Tenchov, 1993, Fig. 6) due to erosion before sedimentation of Velkovo Formation.

In the sequence of the basin above Makedonka Formation specimens of Corynepteris are not found.

Palynomorphs of the type found in Corynepteris sporangia have been found by T. Dimitrova (pers. comm.) in coal seams in the interval with Corynepteris macrofossils, and also at higher stratigraphical levels, up to the base of Krupen Formation (coal seam $n_{3}$ ) in one borehole only (Fig. 4). In these higher stratigraphical levels the spores occur only rarely, and it is possible that they have been reworked, as redeposited coal grains are frequently observed in the associated sediments. 


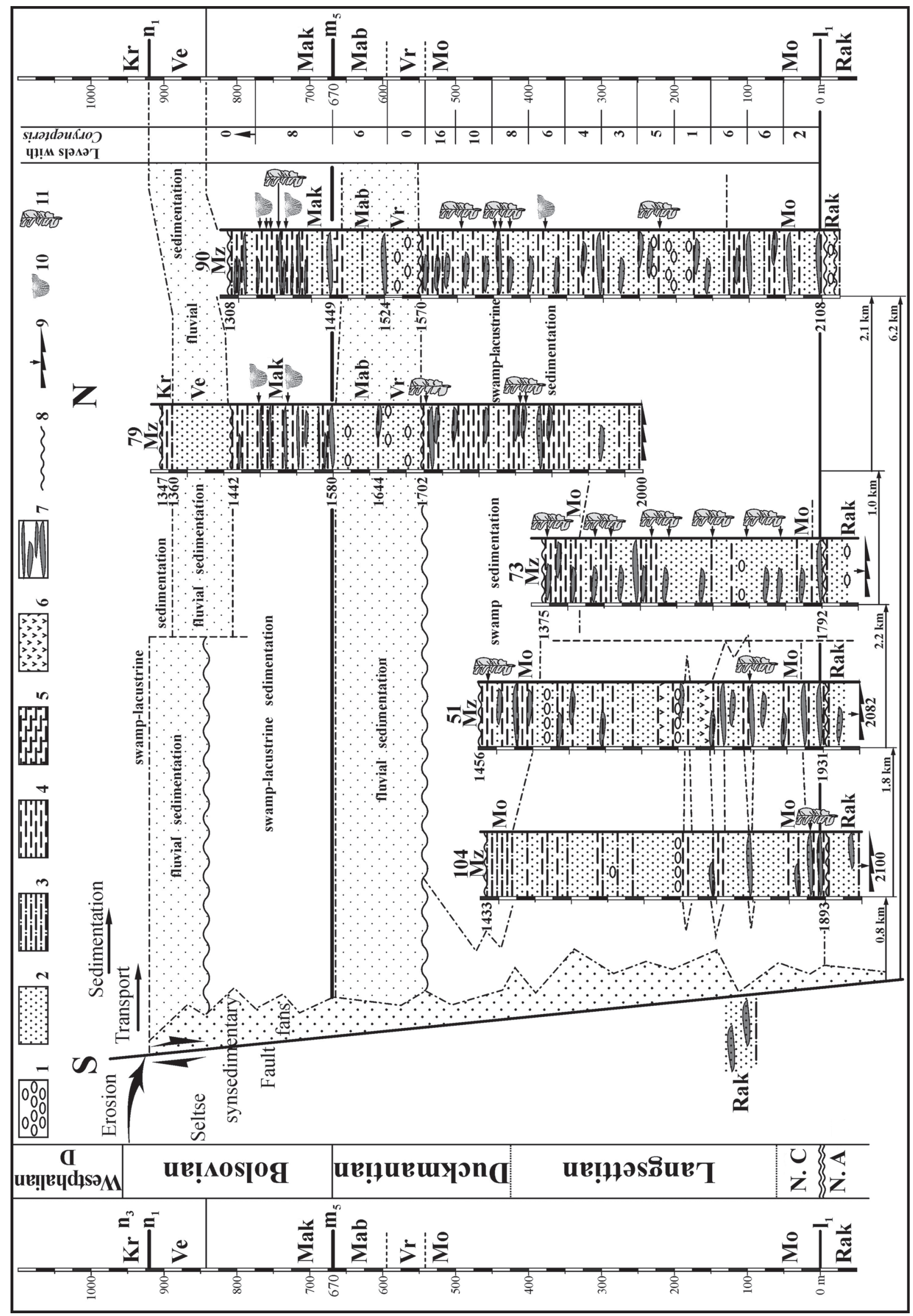


Fig. 4. Profile line approximately from south to north of Dobrudzha Coafield with distribution chart of the established Corynepteris: 1 - pebbles in sandstones; 2 - sandstones; 3 - siltstones; 4 - claystones; 5 - tonsteins; 6 - volcanoclastic sediments; 7 - coals; 8 - erosive boundary; 9 - bottom of the drill; 10 - fresh-water fauna; 11 - findings of Corynepteris; 12 - tie lines; $1_{1}, \mathrm{~m}_{5}, \mathrm{n}_{1}-$ coal seams; Rak - Rakovski Formation; Mo - Mogilishte Formation; Vr - Vranino Formation; Mab - Makedonka Formation bellow $m_{5}$ coal seam; Mac - Makedonka Formation above coal seam $\mathrm{m}_{5}$; Ve - Velkovo Formation; $\mathrm{Kr}$ - Krupen Formation; Mz - Mesozoic cover, mainly Middle Jurassic

In Canadian, western and central European coalfields the genus ranges up to the Westphalian D. In the Czech coalfields, as well as in Saar-Loraine, the genus was present up to the basal part of the Stephanian.

\section{DISCUSSION}

Several possible reasons for the restricted distribution of Corynepteris in Dobrudzha are discussed.

1. The cooling of the Earth's atmosphere by between 7 to $14{ }^{\circ} \mathrm{C}$ as a result of the fossilisation of about 40 billion tons of carbon in the form of coals, mainly during the Langsettian and Bolsovian, is well known as the Carboniferous Glacial Period. The restricted presence of the genus in Svoge Coalfield (Tenchov, 1977), that was maybe 2000 meters above sea level (Tenchov, 1976) supports that cooling is a possible reason. Anyhow, specimens of the genus are extremely rare to the north in the Donets Coalfield Basin and are absent from the Lvov-Volinsk Coalfield. This supports the suggestion that higher temperatures were required for the growth of the genus, and such temperatures did not prevail in the north-eastern part of Europe and in the highly elevated Svoge Coalfield. The value is not determined, but the phytogeographic distribution of the genus to the North of Europe supports such suggestion.

2. The increasing drying of the territory to the north of the Variscan range in Europe is maybe another reason. In Dobrudzha Coalfield it is reflected by thicker cuticles from coal seam m9 upwards (Konstantinova, 1980), where the thicknesses of cuticles increased from 20 to $100 \mu \mathrm{m}$. That is immediately after the Dobrudzha Depression was filled with a considerable mass of volcaniclastic sediments and for some time marsh conditions were discontinued.

3. It may also be a result of changes in habitat in the coalfield after the deposition of the Makedonka Formation. The Makedonka Formation was formed by coals, separated by lake sediments (between coals $\mathrm{m}_{5}-\mathrm{m}_{9}$ ). The sandstones of the Velkovo Formation (59 to $115 \mathrm{~m}$ thick) cover the deeply eroded sediments of the Makedonka Formation. Sandstones are also a major component of the overlying Krupen Formation (especially the 20-30 m between coal seams $n_{2}$ and $n_{3}$ and above) and the Polyantsi Formation. This increase in sandstones coincides with the decrease in abundance of both macrofossils and spores of Corynepteris.

In summary, climatic cooling may have affected the distribution of $C$. essinghii. The influence of drying is not as clearly marked which is normal in a swamp. The repeated destruction of swamp conditions, starting with the total lack of swamps in the depression due to erosion prior to and during the deposition of the Velkovo and Polyantsi formations, obviously influenced the existence of the genus in the Dobrudzha Coalfield. The presence of spores in coal seam $n_{3}$ may indicate a quite restricted preservation of the group, but could alternatively resulted from redeposition of the eroded coal seams of Makedonka Formation.

\section{CONCLUSIONS}

It seems that Corynepteris required permanent high humidity. Some of the species were also sensitive to lower temperatures, such as C. essinghii that is known in Europe only from more southern parts, whereas $C$. coralloides and C. angustissima were distributed in a wider area including the northernmost part of Europe. In the Svoge Coalfield (Tenchov, 2007), which was probably 2000 meters above sea level (Tenchov, 1976), C. angustissima existed for a short time during the Langsettian and early Duckmantian, maybe due to lower temperatures in this highly elevated coalfield. Swamp conditions in the Dobrudzha Coalfield disappeared for some time after coal seam $\mathrm{m} 12$ and before coal seam $\mathrm{n} 1$. However, although the swamps frequently returned between coal seam $\mathrm{n} 1$ and the beginning of deposition of the Gurkovo Formation, conditions were apparently not suitable for the existence of Corynepteris in the region, probably due to a combination of cooling and drying, despite the fact that the genus is known in many other places in Europe at this time.

\section{Acknowledgements}

The author is grateful to IGCP Project 469 for the financial support to visit meetings of the working group. The palynological data used at Figure 1 are kindly provided by Dr. T. Dimitrova.

Prof. Ch. Cleal and Dr I. Lakova are thanked for the improving of text and Dr V. Sachanski for preparing the figures. 


\section{REFERENCES}

Andrae, C. 1865-1869. Vorweltliche Pflanzen aus dem Steinkohlengebirge der preussischen Rheinlande und Westfalens, 50 pp., 15 pts.

Brousmische, C. 1983. Les Fougeres Sphenopteridiennes du Bassin Houiller Sarro-Lorrain. Societe geologique du Nord, Publication N 10, 480 pp., 100 pts.

Daber, R. 1955. Pflanzengeographische Besonderheiten der Karbonflora des Zwickau-Lugauer Steinkohlenreviers. Geologie 12, 44 pp., 25 pts.

Gutbier, A. von. 1835 Versteinerungen des Zwickauer Schwarzkohlen-Gebirges.

Konstantinova, V. 1980. Morphology and distribution of the exinite component in the coals of Dobrudzha Coalfield. Proceedings Geological Institute, Series Oil and Coal Geology, 12, 45-54 (in Bulgarian).

Němejc, F.1938. The Sphenopterides of the Coal Basins in Central Bohemia. I part. Palaeont. Bohemie, 16, 1-56, pl. I-III.

Sternberg, G. K. von. 1820-1838. Versuch einer geognostisch- botanischen Darstellung der Flora der Vorwelt. Bd. I, II, H. $1-8,445$ pp. 127 pts.

Tenchov, Y. 1976. Composition pecularities of the Carboniferous flora of the Svoge Basin, West Bulgaria. Geologica Balcanica, 6(1), 3-11.

Tenchov, Y. 1977. Flora und Biostratigraphie des Oberkarbons in Svoge-Becken (VR Bulgarien). Schriftenr. Geol. Wiss., H. 7, Academie, Berlin, 164 pp., 23 Taf.

Tenchov, Y. 1993. Sedimentation and erosion during the Late Carboniferous in the Dobrudza Coal Field (North-East Bulgaria). Geologica Balcanica, 23(2), 3-18.

Tenchov, Y. 2007. Late Westphalian and early Stephanian sediments of the Dobrudzha Coalfield, NE Bulgaria. Geological Magazine, 144(3), 497-511.

Tenchov, Y. 2007. The Carboniferous of Svoge Coalfield (Bulgaria). Geologica Balcanica, 36(1-2), 5-15.

Zeiller, R. 1886-88. Flore fossile du bassin houiller de Valenciennes. Etud. Gites min. France. 731 pp. 94 pts. 